\title{
161. Oesophagusrekonstruktion bei Sklerodermie
}

\author{
Hiroshi Akiyama \\ Department of Surgery, Toranomon Hospital, 2, Akasaka Aoi-cho, Minato-ku, Tokyo, Japan
}

\section{Esophageal Reconstruction in Scleroderma}

Summary. In a patient with esophageal stenosis due to diffuse scleroderma, the thoracic esophagus with the lesion was extracted by blunt dissection without opening the chest, and the mobilized stomach was brought up to the neck region via a posterior mediastinum and was successfully anastomosed to the cervical esophagus. This type of esophageal reconstruction is believed to be an effective and simple means of providing palliation in this severe clinical situation.

Key words: Reconstruction: Esophagus - Scleroderma - Esophagus, blunt dissection of.

Zusammenfassung. Bei einem Patienten mit Oesophagusstenose bei generalisierter Sklerodermie wurde die thorakale Speiseröhre durch stumpfe Dissection extrahiert und ohne Thorakotomie der mobilisierte Magen durch das hintere Mediastinum hochgezogen und im Halsbereich mit dem cervicalen Oesophagus erfolgreich anastomosiert. Diese Art der Oesophagusrekonstruktion ist eine erfolgreiche und einfache Palliativmethode bei dieser schwierigen klinischen Situation.

Schlïsselwörter: Oesophagus-Rekonstruktion - stumpfe Oesophagusdissektion - Sklerodermie.

\section{Oesophagusrekonstruktion nach Speiseröhrenentfernung}

\author{
Hiroshi Akiyama \\ Department of Surgery, Toranomon Hospital, 2, Akasaka Aoi-cho, Minato-ku, Tokyo, Japan
}

\section{Total Esophageal Reconstruction After Extraction of the Esophagus}

Summary. The operative methods shown are blunt dissection and everting stripping of the thoracic esophagus without thoracotomy, followed by pharyngogastrotomy or pharyngocolostomy as a onestage operation performed through a posterior mediastinal tunnel created by extraction of the esophagus. This operation is recommended for lesions of the hypopharynx, cervical esophagus and, in some cases, of the cardia, as well as for esophageal stenosis, because it is easy and simple to perform, involves little risk, and is rarely followed by postoperative complications. This operation has been successfully performed in 30 cases with no operative mortality.

Key words: Reconstruction: Esophagus - Esophagus, blunt dissection of - Esophagus, extraction of.

Zusammenfassung. Als Operationsmethoden wurden die stumpfe Dissection oder die evertierende Aussteifung des thorakalen Oesophagus ohne Thorakotomie mit Pharyngo-gastro- oder Colostomie in einer Sitzung vorgenommen. Dieser Durchzug im hinteren Mediastinum wird bei Erkrankungen des Hypopharynx, des cervicalen Oesophagus und der Cardia ebenso wie bei Oesophagusstenosen empfohlen. Diese einfache sichere und komplikationslose Methode wurde an 30 Fällen ohne Operationsmortalität ausgeführt.

Schlïsselwörter: Oesophagus-Rekonstruktion - stumpfe Oesophagusdissektion.

163. Zusammenfassung nicht eingereicht. 